\title{
Study of a chemotaxonomic marker able to identify the genus Aquilaria (Thymelaeaceae)
}

\author{
Claude ANDARY, 2 \\ Damien LONGEPIERRE ${ }^{2}$ \\ Kiet LE CONG ${ }^{3}$ \\ Sovanmoly HuL ${ }^{4}$ \\ Alba ZAREMSKI ${ }^{5,6}$ \\ Georges MICHALOUd ${ }^{7}$
}

${ }^{1}$ Retired from Montpellier University Faculty of Pharmacy

Avenue Charles Flahault

34093 Montpellier

France

${ }^{2}$ CEFE

UMR 5175

CNRS

1919 route de Mende

34293 Montpellier

France

${ }^{3}$ Ho Chi Minh University of Natural Sciences 227 Nguyen Van Cu

Q5, Ho Chi Minh City

Vietnam

${ }^{4}$ Muséum National d'Histoire Naturelle 57 rue Cuvier

75005 Paris

France

${ }^{5}$ CIRAD

UMR AGAP

34398 Montpellier

France

${ }^{6}$ AGAP

Univ Montpellier

CIRAD, INRA, Montpellier SupAgro

Montpellier

France

${ }^{7}$ Retired from CNRS

AMAP, Univ Montpellier, CIRAD,

CNRS, INRA, IRD

Montpellier

France

\section{Auteur correspondant /}

Corresponding author:

Claude Andary - claude.andary@gmail.com

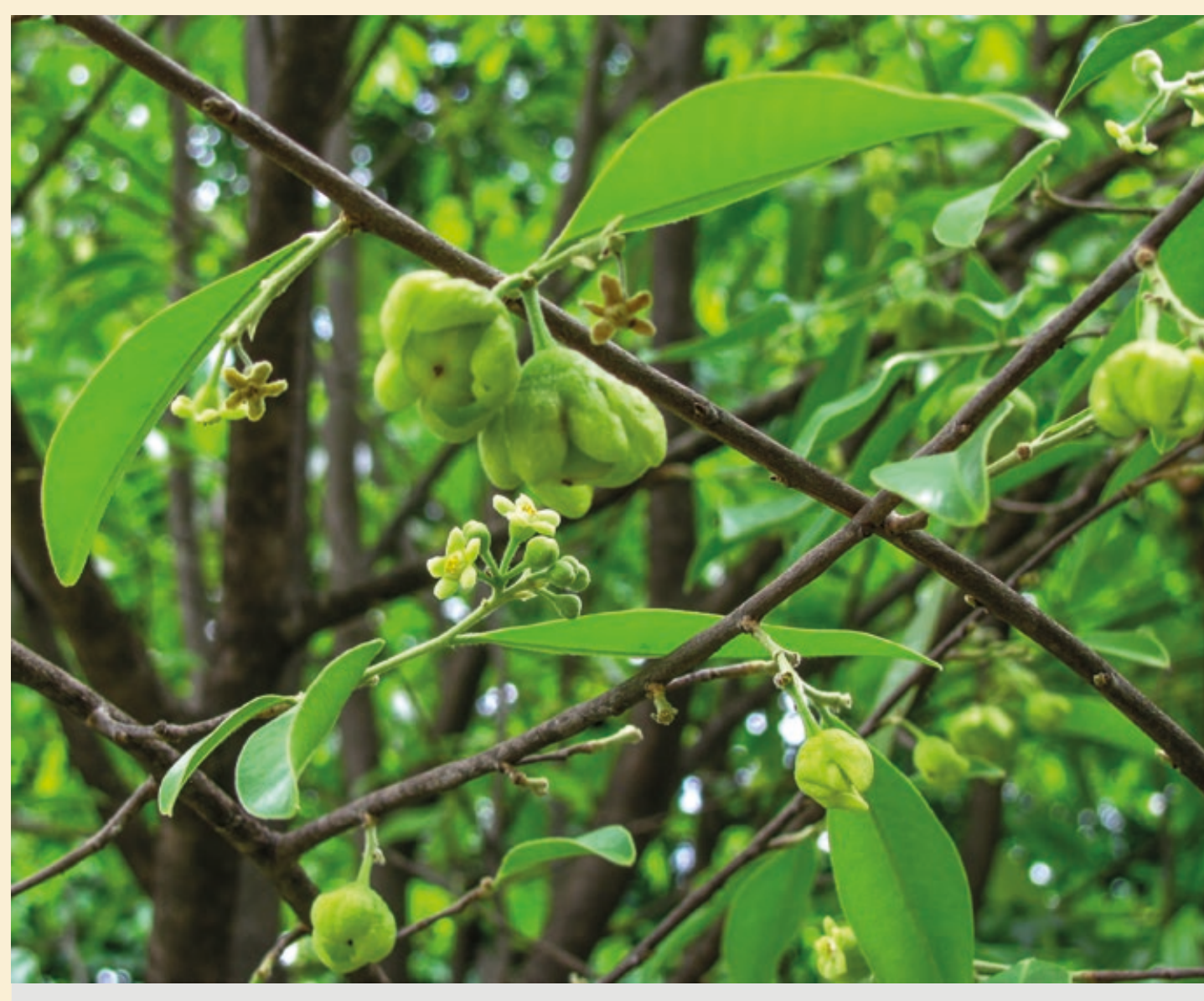

Photo 1.

Aquilaria rugosa: flowers.

Doi : 10.19182/bft2019.341.a31744 - Droit d'auteur @ 2019, Bois et Forêts des Tropiques - @ Cirad - Date de soumission : 5 juillet 2018 ; date d'acceptation : 19 décembre 2018 ; date de publication : $1^{\text {er }}$ juillet 2019.

\section{Cirad (a)}

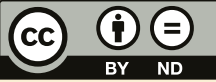

Licence Creative Commons :

Attribution - Pas de Modification 4.0 International.

Attribution-NoDerivatives 4.0 International (CC BY-ND 4.0)
Citer l'article / To cite the article

Andary C., Longepierre D., Le Cong K., Hul S., Zaremski A., Michaloud G., 2019. Study of a chemotaxonomic marker able to identify the genus Aquilaria (Thymelaeaceae). Bois et Forêts des Tropiques, 341: 29-38. Doi: https://doi.org/10.19182/bft2019.341.a31744 


\section{RÉSUMÉ}

\section{Étude d'un marqueur chimiotaxonomique capable d'identifier le genre Aquilaria (Thymelaeaceae)}

Le genre Aquilaria Lam. (Thymelaeaceae) comprend 21 espèces d'arbres (The Plant List, 2013) et se trouve principalement en Asie du Sud-Est. Lorsque l'arbre est infecté (champignons, bactéries), son bois devient brunâtre ou noirâtre (appelé bois d'agar) en raison de la sécrétion d'une oléorésine en réaction à l'infection. La résine est très parfumée et a été recherchée et utilisée pendant des siècles par les bouddhistes, les hindous et les musulmans pour faire de l'encens pour les cérémonies religieuses. Cette oléorésine se trouve principalement dans les espèces du genre Aquilaria, mais aussi dans quelques espèces des genres Gyrinops Gaertner et Gonystylus Teijsmann \& Binnendijk. Il est difficile de faire la distinction entre ces espèces, et ce manque de connaissances taxonomiques a conduit à une surutilisation des arbres, mettant en danger ces espèces endémiques inscrites à l'Annexe II de la CITES. Nous avons utilisé la chimiotaxonomie comme outil de discrimination pour analyser les molécules polyphénoliques, métabolites secondaires, qui sont connus pour agir comme marqueurs taxonomiques dans d'autres plantes. En utilisant une technique d'analyse simple, efficace et peu coûteuse (chromatographie bidimensionnelle en couche mince), nous avons trouvé la même molécule polyphénolique dans les six espèces du genre Aquilaria étudiées, qui a été identifiée comme mangiférine par analyse colorimétrique et chromatographique en comparaison avec la mangiférine de contrôle. Au cours de ces analyses, nous avons trouvé une relation entre les genres Aquilaria et Gyrinops (botaniquement démontrée) par l'existence occasionnelle de mangiférine chez trois espèces du genre Gyrinops. Nous avons également constaté qu'un laps de temps de cent-quarante ans entre deux échantillons d'herbier de la même espèce n'avait pratiquement aucun effet sur la concentration de mangiférine dans la plante. Ces travaux ont montré les mérites de la chimiotaxonomie dans la recherche de marqueurs taxonomiques et l'originalité de l'analyse colorimétrique d'un métabolite de plante chromatographié en couche mince.

Mots-clés : Aquilaria, Thymelaeaceae, chimiotaxonomie, chromatographie bidimensionnelle sur couche mince, mangiférine, Asie du Sud-Est.

\section{ABSTRACT}

\section{Study of a chemotaxonomic marker able to identify the genus Aquilaria (Thymelaeaceae)}

The genus Aquilaria Lam. (Thymelaeaceae) comprises 21 tree species (The Plant List, 2013) and is mostly found in Southeast Asia. When the tree is infected (fungi, bacteria), its wood turns brownish or blackish (then called agarwood) due to the secretion of an oleoresin as a reaction to the infection. The resin is very fragrant and has been sought after and used for centuries by Buddhists, Hindus and Muslims to make incense for religious ceremonies. This oleoresin is mainly found in species of the genus Aquilaria, but also in a few species of the genera Gyrinops Gaertner and Gonystylus Teijsmann \& Binnendijk. It is difficult to distinguish between these species, and this lack of taxonomic knowledge has led to over-use of the trees and endangering these endemic species listed in CITES Appendix II. We used chemotaxonomy as a discrimination tool to analyse polyphenolic molecules, which are secondary metabolites and known to act as taxonomic markers in other plants. Using a simple, effective and inexpensive analysis technique (two-dimensional thin-layer chromatography), we found the same polyphenolic molecule in the six species of the genus Aquilaria we studied, which was identified as mangiferin by chromatographic and colorimetric analysis in comparison with a mangiferin control molecule. During these analyses, we found a relationship between the genera Aquilaria and Gyrinops (botanically demonstrated) in the occasional existence of mangiferin in three species of the genus Gyrinops. We also found that a time laps of 140 years between two herbarium samples of the same species had virtually no effect on the mangiferin concentration in the plant. This study showed the merits of chemotaxonomy in seeking taxonomic markers, and the originality of colorimetric analysis of a thinlayer chromatographed plant metabolite.

Keywords: Aquilaria, Thymelaeaceae, chemotaxonomy, two-dimensional thin-layer chromatography, mangiferin, Southeast Asia.
C. Andary, D. Longepierre, K. Le Cong, S. Hul, A. ZAREMSKI, G. MichaloUd

\section{RESUMEN}

\section{Estudio de un marcador quimiotaxonómico capaz de identificar al género Aquilaria (Thymelaeaceae)}

El género Aquilaria Lam. (Thymelaeaceae) comprende 21 especies de árboles (The Plant List, 2013) y se encuentra principalmente en el Sudeste Asiático. Cuando el árbol está infectado (hongos, bacterias), su madera se convierte en oscura o negruzca (llamada madera de agar) a causa de la secreción de una oleorresina como reacción a la infección. La resina es muy perfumada y ha sido muy buscada y utilizada durante siglos por budistas, hindúes y musulmanes para producir incienso para las ceremonias religiosas. Esta oleorresina se encuentra principalmente en las especies del género Aquilaria, pero también en algunas especies de los géneros Gyrinops Gaertner y Gonystylus Teijsmann \& Binnendijk. Es difícil distinguir estas especies, por lo que la falta de conocimientos taxonómicos ha llevado a una sobreutilización de los árboles, poniendo en peligro estas variedades endémicas inscritas en el anexo II de la CITES. Hemos utilizado la quimiotaxonomía como herramienta de discriminación para analizar las moléculas polifenólicas, metabolitos secundarios conocidos por actuar como marcadores taxonómicos en otras plantas. Utilizando una técnica de análisis simple, eficaz y barata (cromatografía bidimensional en capa fina), hemos encontrado la misma molécula polifenólica en las seis especies del género Aquilaria estudiadas, que ha sido identificada como mangiferina por análisis colorimétrico y cromatográfico en comparación con la mangiferina de control. Durante estos análisis, hemos encontrado una relación entre los géneros Aquilaria y Gyrinops (botánicamente demostrada) por la existencia ocasional de mangiferina en tres especies del género Gyrinops. También hemos constatado que un lapso de tiempo de ciento cuarenta años entre dos muestras de herbario de la misma especie no producía prácticamente ningún efecto en la concentración de mangiferina en la planta. Estos estudios han demostrado el valor de la quimiotaxonomía en la búsqueda de marcadores taxonómicos y la originalidad del análisis colorimétrico de un metabolito de planta cromatografiado en capa fina.

Palabras clave: Aquilaria, Thymelaeaceae, quimiotaxonomía, cromatografía bidimensional en capa fina, mangiferina, Sudeste Asiático. 


\section{Introduction}

The genus Aquilaria Lam. (Thymelaeaceae) is widespread from India to the island of New Guinea and more particularly in Southeast Asia as far as southern China. When the wood of certain species of Aquilaria is wounded and/or contaminated by a pathogen (e.g. a fungus), its defence strategy consists in secreting a very fragrant oleoresin, which plays a role in transforming the heartwood, which then becomes known as "Agarwood” (or Eagle Wood or Oud or Gaharu...).

The oleoresin secreted in the wood consists of a complex mixture of sesquiterpenes, phenylethylchromones and minor aromatic compounds, which give the warm, persistent and much appreciated aroma that particularly develops when the wood is heated. Agarwood has been used by Buddhists, Hindus and Muslims for centuries to make incense used in religious ceremonies (Qi et al., 2005). With its medicinal properties, this oleoresin also plays an important role in traditional Chinese, Tibetan and Ayurvedic medicines, and is used as a sedative, analgesic, cardiotonic, antirheumatic, etc. (Ueda et al., 2006; Feng et al., 2009; Qi et al., 2009). The essential oils obtained by distilling agarwood are used in perfumery (such as “M7”, a perfume by Yves Saint Laurent).

It is worth noting that the economic value of the products obtained from Aquilaria is very high; $1 \mathrm{~kg}$ of essential oil obtained from agarwood costs at least 10,000 USD and $1 \mathrm{~kg}$ of incense obtained from the same wood costs around 1,000 to 1,300 USD.

The chemical composition of the oleoresin has already been analysed (see overview by Naef, 2011), but it cannot be used to sufficiently distinguish between the species. Oleoresin is mostly produced by species of the genus Aquilaria but also by some species of the genera Gyrinops Gaertner and Gonystylus Teijsmann \& Binnendijk. The species of the last two genera are also difficult to distinguish from each other, but they might be a substitute for Aquilaria agarwood and form part of a preservation policy. This lack of taxonomic knowledge for these Asian species producing agarwood has led to over-use of the trees, endangering 17 endemic species of Aquilaria (Mabberley, 2008), which are all listed in CITES Appendix II.

As commercial use of these oleoresins is only possible with reliable knowledge of the species and with strict traceability, we used a chemotaxonomy analysis as a discrimination tool.

To that end we opted to study polyphenols, which are secondary metabolites found throughout the Plant Kingdom, but in highly varied forms. A composition difference in these metabolites is less often due to a fluctuation in the surrounding environment than to a genotypic difference, hence the taxonomic value of these substances (Bell, 1981). Polyphenol molecules are mainly synthesized in leaves and their role as chemotaxonomy markers has been demonstrated in numerous plants (Harborne et al., 1971; Bate-Smith and Richens, 1973; Cooper-Driver and Swain, 1977; Andary et al., 1988b; Williams et al., 1988; Andary et al., 1992).

Earlier research showed the existence of several types of polyphenols in Aquilaria spp. leaves: benzophenones (e.g. iriflophenone; Feng et al., 2009), xanthone (e.g. mangiferin; Qi et al., 2009), flavonoids (e.g. genkwanin, derivatives of luteolin and apigenin; Hara et al., 2008; Qi et al., 2009).

We conducted this study by comparing a batch of 40 specimens belonging to the genus Aquilaria (botanically analyzed) collected and dried in Laos and Cambodia, and some reference samples from the herbaria of Paris Museum (P) and Leiden (L). The latter samples corresponded to voucher species belonging to some close genera: Aquilaria, Gyrinops, Gonystylus and Wikstroemia Endlicher. Aquilaria and Gyrinops are classified in the sub-family of the Aquilarioideae, Gonystilus in that of the Gonystiloideae and Wikstroemia in that of the Thymelaeoideae. These three sub-families, with that of the Gilgiodaphnoideae, make up the family of the Thymelaeaceae (Hou, 1960). These subfamilies, apart from the Gilgiodaphnoideae, are endemic to southern, tropical Asia.

We also took as an example of the use made of the genus Aquilaria, other than for its oleoresin, a quality study involving the analysis of a herbal tea comprising Aquilaria spp. leaf fragments, marketed as "Agarwood Tea".

This chemotaxonomy analysis was carried out by two-dimensional thin-layer chromatography (quick and inexpensive method). The nature of the studied molecule was suggested by the position of each spot on the chromatogram, confirmed by comparison with the reference molecule and by a colorimetric analysis of the amount of colour in the Red, Green and Blue channels. This approach was totally original.
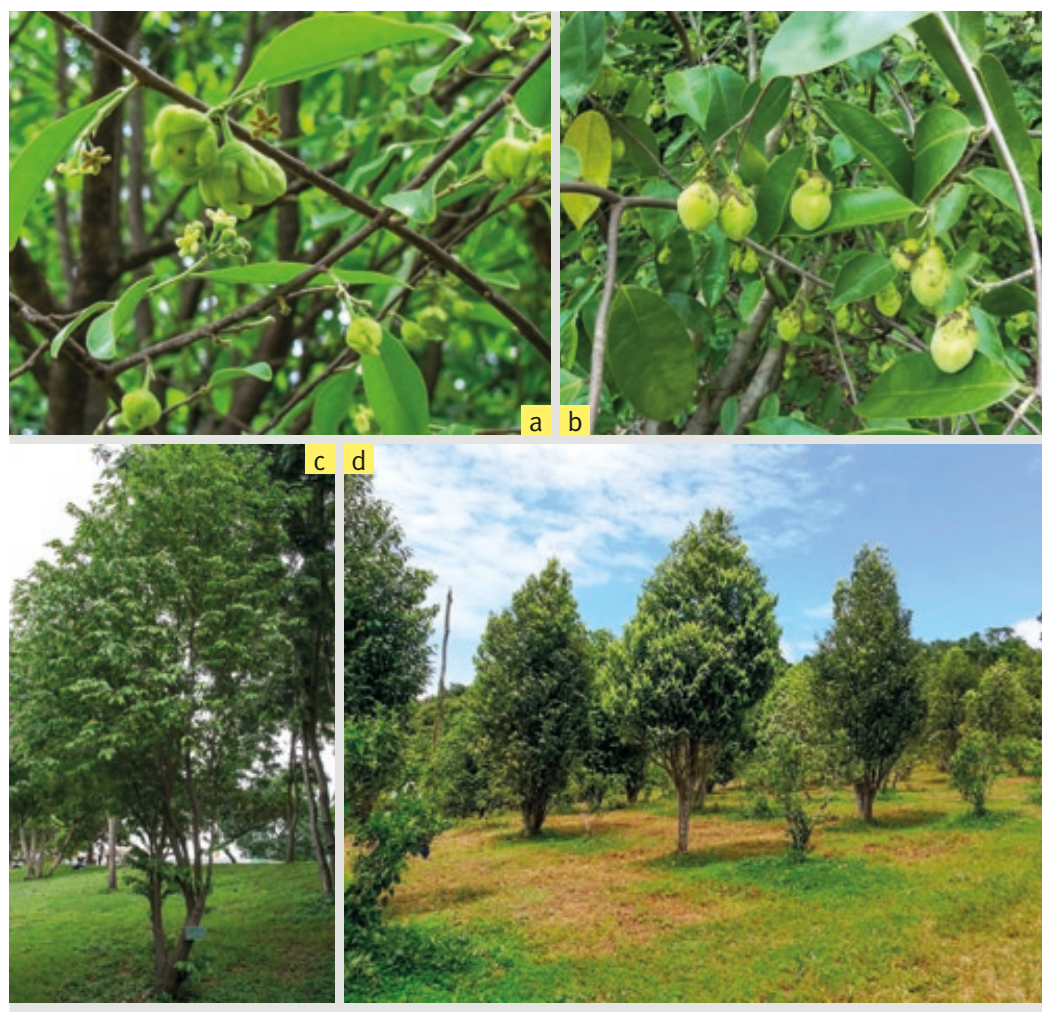

Photos 2.

Aquilaria rugosa: flowers (a); fruits (b); tree (c); trees in plantation (d). 


\section{Methodology}

\section{Plant material}

Forty specimens of Aquilaria spp. from Laos (24) and Cambodia (16) were collected and dried. We also studied a sample of Aquilaria crassna Pierre ex. Lecomte collected and dried in 2010 and kindly offered by Professor Kiet Le Cong in Vietnam.

Ten voucher specimens were provided by the National Natural History Museum (MNHN) in Paris (P):

- Aquilaria agallocha Roxb., Vidal 5800 (Thailand);

- Aquilaria baillonii, Chevalier 38441 (Indochina);

- Aquilaria baillonii, Poilane 30000 (Indochina);

- Aquilaria crassna Pierre ex Lecomte, Bejaud 364

(Cambodia);

- Aquilaria crassna Pierre ex Lecomte, Chevalier 1365

(Indochina);

- Aquilaria crassna Pierre ex Lecomte, Pierre 3619 Holotype (Cambodia);

- Aquilaria malaccensis Lam., Griffith 4382 (Burma)

Malaysia);

- Aquilaria sinensis (Lour.) Spreng., Lei 864 (Hainan);

- Aquilaria sinensis (Lour.) Spreng., Bodinier 134

(Hong-Kong);

- Aquilaria sinensis (Lour.) Spreng., Chan 1047

(Hong-Kong).

And 12 specimens were provided by the National herbarium of Leiden $(\mathrm{L})$, the Netherlands:

- Aquilaria rugosa L. C. Kiet \& Kessler, Kiet 1940 Holotype (Vietnam);

- Aquilaria rugosa L. C. Kiet \& Kessler, Kiet 1941 (Vietnam);

- Gyrinops caudata (Gilg) Domke, Hou 10629 (Indonesia);

- Gyrinops ledermannii Domke, Singadan 02 (New Guinea);

- Gyrinops walla Gaertn., Ridsdale 465 (South India);

- Gonystylus bancanus (Miq.), Kurz Awang Awang Irang SAN

97436 (Malaysia);

- Gonystylus confusus Airy Shaw, Niyomdham 960

(Thailand);

- Gonystylus velutinus Airy Shaw, Ambri W528 (Indonesia);

- Wikstroemia indica (L.) C.A. Mey., Hou 7612 (Thailand);

- Wikstroemia meyeniana Warb., Hou 6279 (Cambodia);

- Wikstroemia polyantha Merr., Maxwell 76-558 (Thailand);

- Wikstroemia ridleyi Gamble, Niyomdham \& Sriboonma 1631 (Thailand).

Altogether, we analysed 6 Aquilaria species and 10 species belonging to three other genera: Gyrinops, Gonystylus, and Wikstroemia.

\section{Chromatographic analyses}

For these chemotaxonomy studies, we chose to analyse polyphenol compounds from dried leaves. All the solvents were of "analysis" quality (VWR, France) and were as follows: acetic acid, hydrochloric acid, dichloromethane, ethanol and methanol.

\section{Preparation of plant extracts}

The dried leaves were weighed out and ground in an electric grinder, then extracted at a rate of $0.2 \mathrm{~g}$ of plant in $10 \mathrm{ml}$ of $80 \%$ methanol. Extraction was achieved by magnetic stirring at room temperature for $1 \mathrm{~h}$. The resulting extract was filtered through filter paper (Labover, France) and the filtrate stored in brown glass bottles.

\section{Two-dimensional thin-layer chromatography (2D TLC)}

Two-dimensional thin-layer chromatography involves using thin layers of cellulose industrially deposited on $20 \times 20 \mathrm{~cm}$ aluminium plates (ref. 5552, Merck). Each plate was cut into four $10 \times 10 \mathrm{~cm}$ squares. After the extract to be analysed had been deposited on one of the $10 \times 10 \mathrm{~cm}$ squares, it underwent successive migrations perpendicular to each other (called first migration and second migration) in glass tanks (dimensions: $10 \times 10 \times 8 \mathrm{~cm}$, ref. 022.510; CAMAG, France), using the following migration solvents:

- For type A polyphenols (flavonoids, coumarins, caffeic acid derivatives, xanthones, etc.):

- solvent 1 (first migration): ethyl acetate - acetic acid water (49:45:15; v/v);

- solvent 2 (second migration): ethyl acetate - acetic acid water (10:30:70; v/v).

Solvent migration was halted $0.5 \mathrm{~cm}$ from the top of the plate for each solvent.

- For type B polyphenols (monomeric and oligomeric catechic tannins):

- a single migration with acetic acid - water (2:98; v/v).

Solvent migration was halted $0.5 \mathrm{~cm}$ from the top of the plate.

\section{Reference extract and molecule depositing}

The reference molecules (supplied by Extra-Synthèse or Roth Sochiel, France) were as follows: acacetin, apigenin, apigenin-7-0-glucoside, caffeic acid, chorogenic acid, daphnetin, esculetin, fraxetin, genkwanin, isoorientine, kaempferol, luteolin, luteolin-7-0-glucoside, mangiferin, orientin, quercetin, scopoletin, rutin and vitexin.

Each reference molecule was solubilized to $0.5 / 1,000$ in methanol then deposited on a chromatography plate at a rate of $1 \mu \mathrm{l}$ of solution with a $1 \mu \mathrm{l}$ micropipette (Microcaps Drumond, France).

Each plant extract to be analysed was deposited on a chromatography plate at a rate of $15 \mu \mathrm{l}$ (using a $5 \mu \mathrm{l}$ micropipette, Microcaps Drumond, France).

The chromatography of each extract was repeated three times.

\section{Mangiferin internal standard technique}

We also applied the mangiferin internal standard technique for all the species: $1 \mu$ l of mangiferin standard solution was added to the $15 \mu$ l of plant extract deposited on the thin layer of cellulose. This result was compared to a chromatograph of the same plant extract without added mangiferin. 


\section{Visualization and interpretation of the chromatograms}

The plates were carefully dried with an electric hairdryer following each migration.

The chromatograms were observed either in natural light, or under UV light, before and after spraying (sprayer ref. 022.6100, CAMAG, France) and drying the reagent specific to each of the two chemical groups (type A and type B): - For type A polyphenols (flavonoids, coumarins, caffeic acid derivatives, xanthones):

- Neu's reagent (Neu, 1956): 1\% amino-2-ethyldiphenylborinate in methanol (Sigma-Aldrich, France).

Type A polyphenols appear under UV light with specific fluorescences, ranging from blue to red, with intermediate colours depending on the chemical group. The colours are as follows (Dai et al., 1995):

- flavonoids: yellow fluorescence in general but can range from yellow to red;

- coumarins: fluorescence that can range from blue to whitish blue;

- caffeic acid derivatives: more or less bright whitish blue fluorescence;

- hydroxyxanthones: more or less pale yellow fluorescence.

However, the need to photograph the chromatograms to record the phenolic profiles of each extract sometimes raises a problem of colour rendition. For example, mangiferin, which, is seen with the naked eye as pale yellow fluorescence, appears more whitish on a photo.

- For type B polyphenols (flavan nuclei making up the more or less polymerized catechic tannins):

- DMCA reagent (dimethylaminocinnamaldehyde (Merck, France) at $0.1 \%$ in $\mathrm{HCl}-\mathrm{MeOH}$ (10:90); Mc Murrouch and McDowell, 1978).

Catechic tannins appear with green colorations for polymers and blue for oligomers, under natural light, without noteworthy fluorescence under UV light.

\section{Chromatogram photography technique after visualization}

Each chromatogram was placed in a photo chamber lit by a UV lamp (giving wavelengths of 254 or $366 \mathrm{~nm}, 2 \times 8 \mathrm{~W}$, Ref: 022.970, CAMAG, France). There was a hole at the top of the chamber to position a camera (Compatc, Panasonic - Lumix, DMC-FS10: 12 megapixels) to photograph the chromatograms (figure 1).

The distances and shots were identical for all the chromatograms.

\section{Colour analysis method for fluorescence spots}

After chromatography and photographing of the chromatogram, the fluorescent spots of the Type A molecules were measured by software (GIMP image editor, Google) that measured the colour of the molecule for the three channels, Red, Green and Blue (as a \%), along with the Hue (in ${ }^{\circ}$ ) and Saturation (as a \%).

Our measurements were taken in the centre of the spot and validated by 3 replications.

\section{Results}

Figure 2 shows the chromatographic image of a mixture of several reference molecules likely to be found in Aquilaria or other close genera (Gyrinop, Gonystylus, Wikstroemia) as mentioned in the introduction. In addition, colorimetric analyses of coloured spots corresponding to those molecules also showed us the possibility of distinguishing each molecule (table I).

An initial, unexpected result, was found when we compared holotype $N^{\circ} 3619$ of Aquilaria crassna Pierre ex. Lecomte, collected in 1870 and conserved at the MNHN herbarium (P), with a sample of the same species collected and dried in 2010 by Professor Kiet Le Cong in Vietnam. When analysed under the same conditions, these two samples gave an analogous chromatographic image despite the 140year difference in age between the two specimens, with only slightly toned-down fluorescence for the older one (figure 3).

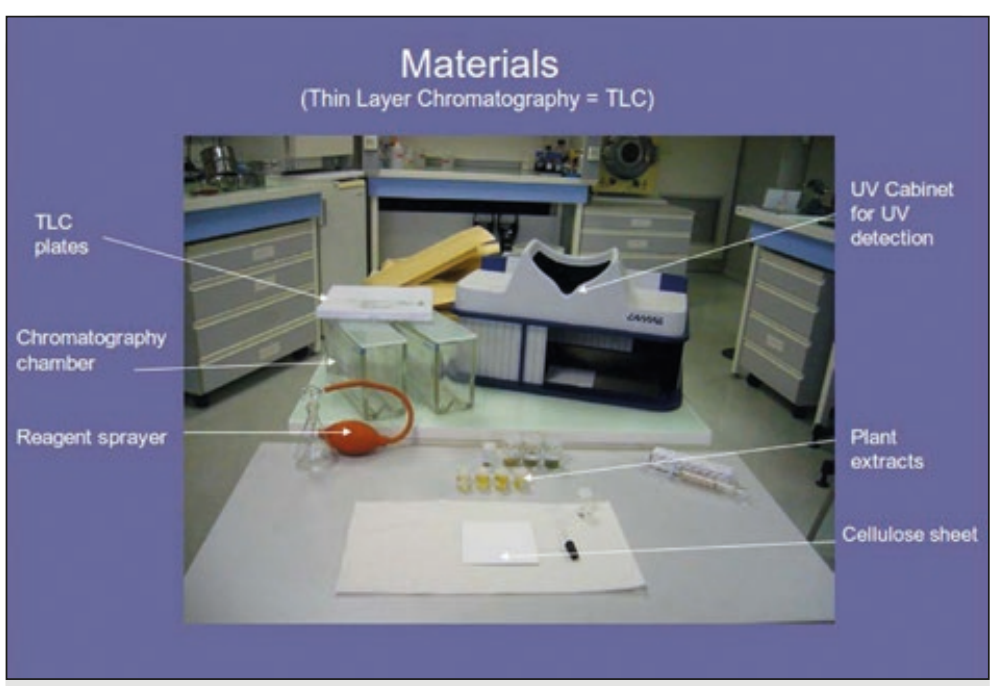

Figure 1.

Visualization of the thin-layer chromatography (TLC) material.

\section{TLC reference samples}

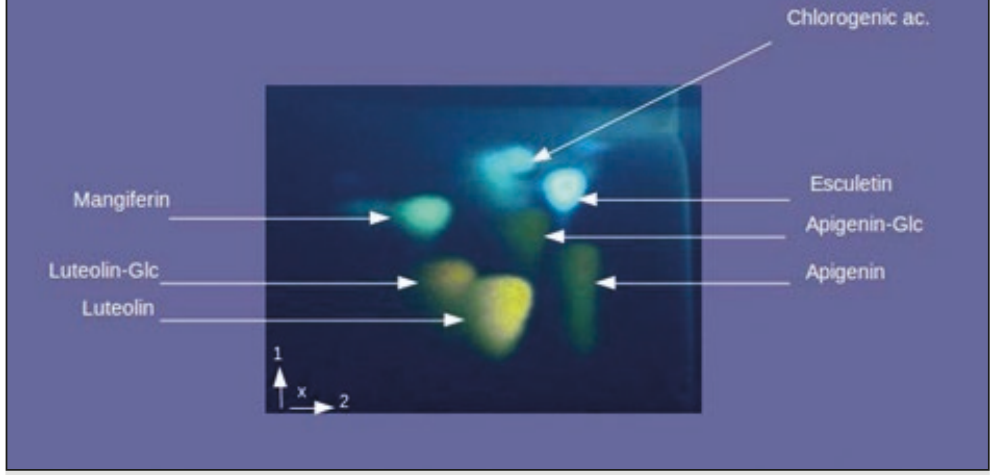

Figure 2.

2D TLC (two-dimensional thin-layer chromatography) of the different standard molecules after visualization with Neu's reagent. 1 and 2 are the order and two directions of migration of the two chromatographic solvents. $X$ is the deposit of the solution to be chromatographed. 
In the different species of the genus Aquilaria, we were able to identify mangiferin (C-glucoside of dihydroxyxanthone) (figure 4) by chromatographic and colorimetric comparison (measurement of colour parameters) with a reference mangiferin molecule (also used as an internal standard). In fact, the colorimetric analysis of all the spots corresponding to mangiferin found in the different taxa analysed gave results equivalent to the mangiferin standard (tables Ila and IIb). Alongside this molecule, we also found several flavonoids of the flavone group (particularly derivatives of luteolin and apigenin), along with some coumarins.

However, out of the six species of the Aquilaria genus studied, only one, A.baillonii (also noted as Gyrinopsis baillonii by Poilane) bearing the herbarium number 30000 (Poilane herbarium, MNHN), did not reveal the existence of mangiferin on the chromatographs (figure 4), whereas in the same MNHN herbarium, another sample bearing the same name, $A$. baillonii, number 38441 (Chevalier herbarium, MNHN) effectively corresponded to the expected chromatographic profile (with mangiferin) for species of the genus Aquilaria.

Within the genera Gonystylus and Wikstroemia, we were able to verify the absence of mangiferin in the different species studied. Indeed, we used the internal standard technique for mangiferin on all these species (see Methodology).

In addition, with the $W$. indica chromatogram (figure 5), we were able to see the presence of caffeic acid derivatives (dihydroxycinnamic acid derivatives) recognizable by their typical blue fluorescence, which we also found in the four species of Wikstroemia analysed.

The analysis of the type B polyphenols (molecules with a flavan nuclei ex: tannins) showed a variable standard pattern that was difficult to interpret by our chromatographic tests, be it in Aquilaria or in the other genera. An example of the visualization of these tannins can be seen in figure 6 with sample $N^{\circ} 2$, which shows an overall image of the tannins found in Aquilaria.

We then analysed the dried samples from Laos (24 samples) and Cambodia (16 samples) labelled "Aquilaria". The chromatographic profile of each sample was compared to that of the different voucher species (cf. Leiden ( $L$ ) and Paris herbaria (P)). All these samples displayed a polyphenol profile very close to the standard schematic profile found in the genus Aquilaria.

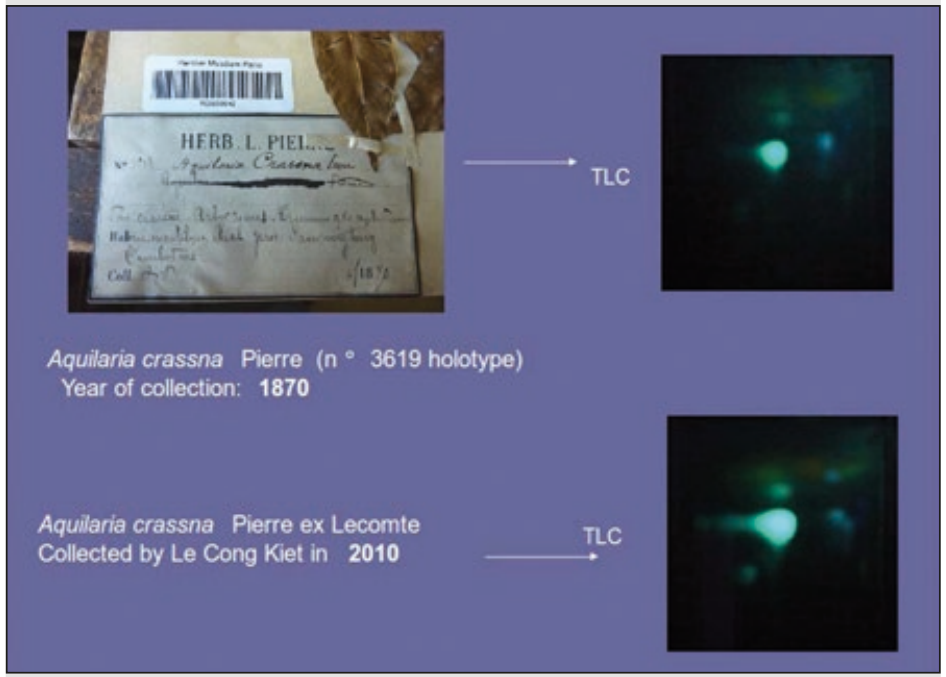

Figure 3.

2D TLC comparing a sample from the holotype for the species Aquilaria crassna with the sample of the same species collected 140 years later.

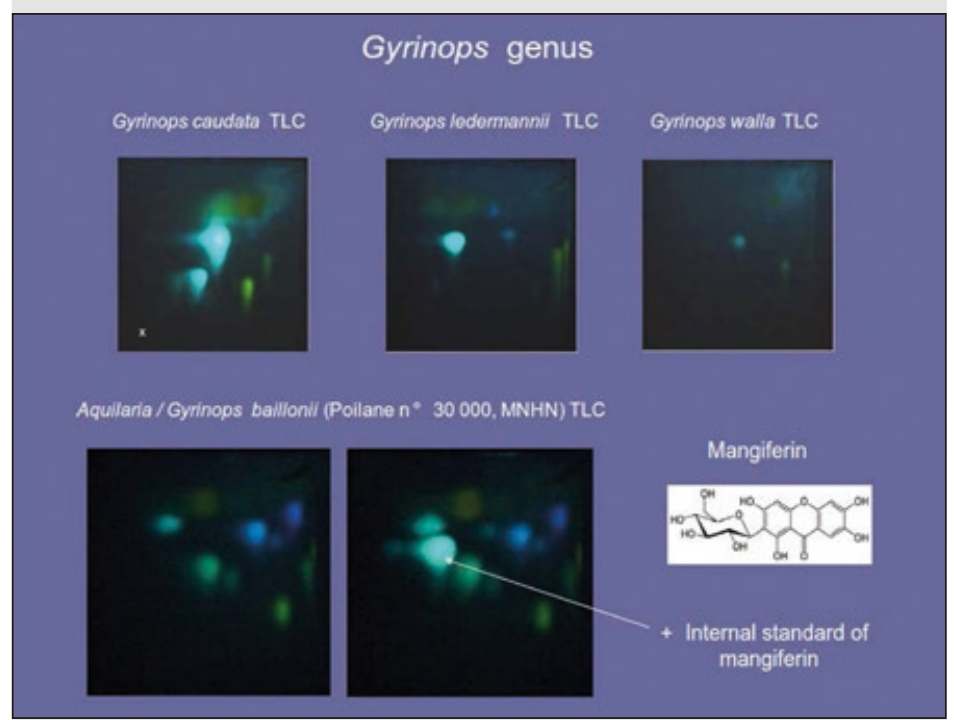

Figure 4.

Chromatographic (2D TLC) comparison between three species of Gyrinops: G. caudata, G. ledermannii and G. walla. Use of a mangiferin internal standard on the 2D TLC of the species Aquilaria/Gyrinops baillonii to check for the absence of that molecule in the species.

Table I.

Assessment of the amount of Colour (as a \%), Hue (in ${ }^{\circ}$ ) and Saturation (as a \%) by standard-molecule for the three channels: red, green and blue (R,G, B); Glc: glucoside.

\begin{tabular}{|c|c|c|c|c|c|c|c|}
\hline & Mangiferin & Luteolin & Luteolin-GIc & Apigenin & Apigenin-Glc & Chlorogenic acids & Esculetin \\
\hline Red & 15 & 71 & 89 & 31 & 32 & 72 & 79 \\
\hline Green & 100 & 73 & 92 & 41 & 42 & 100 & 100 \\
\hline Blue & 100 & 39 & 46 & 29 & 31 & 94 & 95 \\
\hline Hue & 180 & 64 & 63 & 110 & 114 & 167 & 166 \\
\hline Saturation & 65 & 60 & 62 & 55 & 59 & 75 & 60 \\
\hline
\end{tabular}


Table Ila.

Comparative measurements of the different colorimetric parameters for mangiferin

(Red, Green, Blue, Hue and Saturation) for each species of the genus Aquilaria analysed (collector name).

\begin{tabular}{|l|c|c|c|c|c|c|}
\hline & $\begin{array}{c}\text { Aquilaria } \\
\text { crassna } \\
\text { (Pierre) }\end{array}$ & $\begin{array}{c}\text { Aquilaria } \\
\text { crassna } \\
\text { (Bejaud) }\end{array}$ & $\begin{array}{c}\text { Aquilaria } \\
\text { baillonii } \\
\text { (Chevalier) }\end{array}$ & $\begin{array}{c}\text { Aquilaria } \\
\text { crassna } \\
\text { (Le Cong) }\end{array}$ & $\begin{array}{c}\text { Aquilaria } \\
\text { rugosa } \\
\text { (Le Cong) }\end{array}$ \\
\hline Red & 8 & 24 & 42 & 45 & 54 & $\begin{array}{c}\text { Aquilaria } \\
\text { crassna } \\
\text { (Chevalier) }\end{array}$ \\
\hline Green & 100 & 100 & 100 & 100 & 100 & 100 \\
\hline Blue & 95 & 98 & 100 & 98 & 100 & 100 \\
\hline Hue & 177 & 178 & 180 & 178 & 180 & 180 \\
\hline Saturation & 92 & 76 & 58 & 55 & 46 & 40 \\
\hline
\end{tabular}

\begin{tabular}{|c|c|c|c|c|}
\hline \multicolumn{5}{|c|}{$\begin{array}{l}\text { Table Ilb. } \\
\text { Comparative measurements of the different colorimetric parameters for mangiferin } \\
\text { (Red, Green, Blue, Hue and Saturation) for each species of the genus Aquilaria analysed (collector name). }\end{array}$} \\
\hline (Collector name) & $\begin{array}{c}\text { Aquilaria sinensis } \\
\text { (Lei) }\end{array}$ & $\begin{array}{l}\text { Aquilaria sinensis } \\
\text { (Bodinier) }\end{array}$ & $\begin{array}{l}\text { Aquilaria sinensis } \\
\text { (Chan) }\end{array}$ & $\begin{array}{c}\text { Aquilaria malacensis } \\
\text { (Griffith) }\end{array}$ \\
\hline Red & 16 & 27 & 29 & 48 \\
\hline Green & 100 & 100 & 100 & 100 \\
\hline Blue & 85 & 95 & 88 & 100 \\
\hline Hue & 169 & 176 & 170 & 180 \\
\hline Saturation & 84 & 73 & 71 & 52 \\
\hline
\end{tabular}

As regards the quality analysis applied to the sample of Aquilaria spp. leaf fragments “Agarwood Tea”, we analysed sachets from two different places. Firstly some sachets from Laos (small-scale production, No. 1) and some sachets from Vietnam (industrial production, No. 2).

We analysed type A and type B polyphenols (see methodology) from the sachet contents. Interpretation of the chromatograms for the two sachets (Nos. 1 and 2) showed us that the type A polyphenol profiles found in Aquilaria were closely related (especially for mangiferin) (figure 6). However, the interpretation of the chromatographic profile of type $B$ polyphenols (tannins) indicates that only Agarwood Tea $\mathrm{N}^{\circ} 2$ corresponds overall to the profile of tannins found in Aquilaria.

\section{Discussion}

We chose a rapid, simple and inexpensive chromatographic analysis method to analyse our leaf extracts: two-dimensional cellulose thin-layer chromatography. This method offers greater accuracy than conventional one-dimensional chromatography. In fact, the positioning of the spots on the chromatogram is stricter and more reproducible, and the separation between spots is more efficient as each molecule migrates in two perpendicular directions, with a different

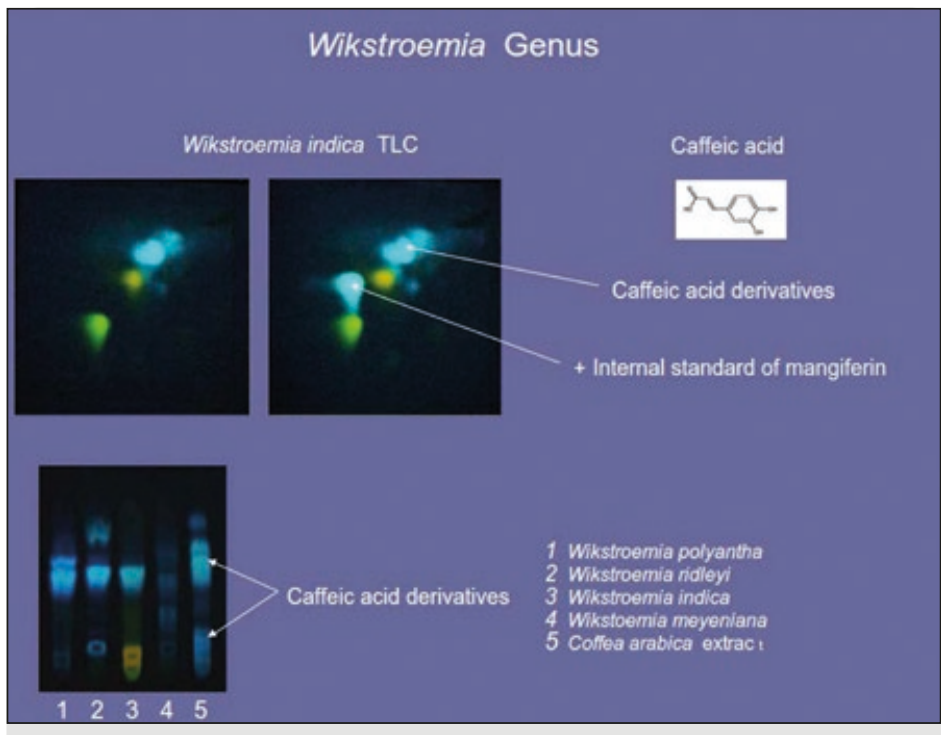

Figure 5.

Checking for the absence of mangiferin in Wikstroemia indica by the mangiferin internal standard technique (2D TLC) and for the presence of caffeic acid derivatives in the four species of Wikstroemia studied by one-dimensional TLC (with Coffea arabica extract as reference to caffeic acid derivatives). 
elution solvent each time, hence with different separating power. Using thin layers of cellulose also prevents the oxidation of polyphenols, thus leading to high detection sensitivity, unlike the usual thin layer of silica gel.

Lastly, adding colorimetric analysis (measurement of the quantities of colour for the three channels: Red, Green and Blue) of the spots corresponding to the different molecules was very valuable, as it provided further confirmation of the identification of the analysed molecules. Among the values obtained, it was the "Hue" parameter that was most stable and which differentiated between mangiferin and the other molecules (table I), among other things.

In addition, we found that the colorimetric values obtained for mangiferin (which was found in each of the species of Aquilaria and in some of the species of Gyrinops analysed) were highly comparable for Blue and Green (tables $\mathrm{Ila}$, Ilb and III). However, the Red values varied (from 8 to 58, tables Ila and Ilb) depending on some parameters that we were unable to control, such as concentrations, physiological stages, environmental conditions, etc. The Red values were also found to be inversely proportional to the Saturation obtained with the software used (GIMP colour editor, Google).

This type of identification by colorimetric analysis of molecules is very simple, inexpensive and, to our knowledge, has never been used before directly on thin-layer chromatograms. This method is perfect for analysing plant polyphenols, due to its sensitivity and specificity arising from the use of an identification reagent (Neu's reagent), sensitive to within a nanogram of detected substance (Andary et al., 1978), inducing different fluorescence colorations for most of the chemical groups studied.

It should also be noted that application of this type of chromatography has proved very useful in the field, thanks to the development of a micro-chromatography kit using thin layers, enabling the simplified, but immediate analysis of leaves collected on site (Andary et al., 1989).

Initially, we set out to check whether we could detect polyphenol molecules in both fresh and dried leaves, bearing in mind that herbarium samples may have been stored for numerous years and may also have undergone chemical decontamination. The result of this analysis showed that the polyphenol molecules of the leaves were well conserved and stood the test of time (140 years in our case), in their phytochemical environment in planta (figure 3). values, which was normal according to the scale of RGB values

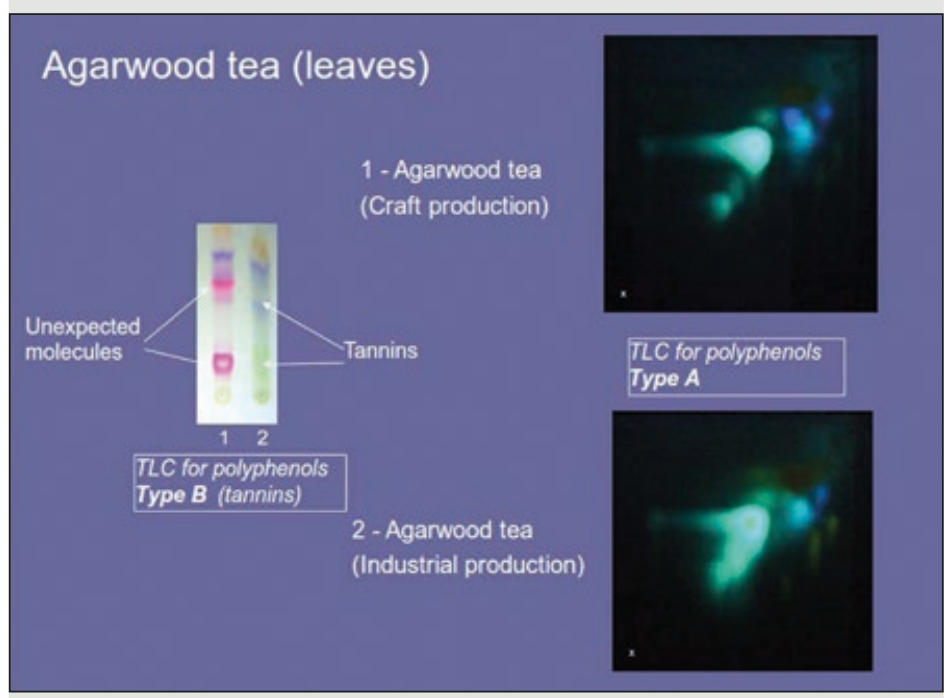

Figure 6.

Two-dimensional chromatography (type A polyphenols) and onedimensional chromatography (type B polyphenols) of extracts 1 and 2 of Aquilaria Tea (leaves). For the type A polyphenols, the chromatograms are similar for the two extracts: smallscale production (1) and industrial production (2). For the type B polyphenols, the chromatogram shows a large difference between extracts 1 and 2 . Only extract 2 displays the usual chromatographic pattern for tannins in Aquilaria. Extract 1 reveals unexpected molecules (shown in red) in this profile.

Chromatographic analysis of the different species showed us that the genus Aquilaria had a large number of type A polyphenols compared to the other three genera studied (Gyrinops, Gonystylus and Wikstroemia). Of these different polyphenols, mangiferin was the majority polyphenol in the six Aquilaria species analysed. Given the constant presence and high concentration of this molecule, we were able to consider it a chemotaxonomic marker of the genus Aquilaria.

It also turned out that this difference, the presence/ absence of mangiferin, tallied with the doubt expressed by Poilane surrounding the identification of herbarium sample No. 30000. It should be noted that it is often very difficult to delimit species within the Thymelaeaceae. For instance, as indicated by Hou (1960), an important botanical feature for recognizing species belonging to a given genus may be missing in one or two species, thereby making identification of that genus less reliable. One example is the stamens that are generally free in the genus Aquilaria, and can be partially attached to the floral tube in some specimens, as in A. cumingiana (Decne.) Ridle.

\section{Table III.}

Comparative measurements of the different colorimetric parameters for mangiferin (R, G,B, Hue and Saturation) for each species of Gyrinops analysed.

\begin{tabular}{l|c|c|c|} 
Collector & $\begin{array}{c}\text { Gyrinops walla } \\
\text { Ridsdale }\end{array}$ & $\begin{array}{c}\text { Gyrinops ledermannii } \\
\text { Singadan }\end{array}$ & $\begin{array}{c}\text { Gyrinops caudata } \\
\text { Hou }\end{array}$ \\
\hline Red & 0 & 11 & 51 \\
\hline Green & 27 & 100 & 100 \\
\hline Blue & 31 & 100 & 100 \\
\hline Hue & 186 & 180 & 180 \\
\hline Saturation & 100 & 89 & 49 \\
\hline
\end{tabular}

Distinguishing between the different species of Aquilaria remains tricky, even in the presence of flowers and fruits, which are essential elements in recognizing plant species. In this case, the search for specific or generic chemical markers may be of great help in distinguishing between close genera, or better still, between species. Thus, Gyrinopsis Decne. has been considered as a section of the genus Aquilaria and even subsequently a synonymy of the genus Aquilaria (Hallier, 1922). 
In the more recent classification of the Thymelaeaceae by Hou (1960), for the 12 species described for Aquilaria in Malaysia, seven species would appear to belong to the genus Gyrinopsis. The same author also demonstrated the close proximity that exists between the genus Aquilaria and the genus Gyrinops, though without merging these two genera. It turned out that the doubt expressed by Poilane regarding the identification of Aquilaria baillonii was backed up by our chemical analysis of the three species of the genus Gyrinops in which the mangiferin concentration was highly variable. In fact, in $G$. caudata and $G$. ledermannii, mangiferin was present (in different concentrations), whilst in the species $G$. walla there were only traces (figure 4). However, the role of mangiferin as a marker of the genus Aquilaria remains valid as this molecule not only marks species of this genus in a definite way, but also indicates the great phylogenetic proximity between Aquilaria and Gyrinops as well shown by Eurling and Gravendeel (2005) with phylogenetic analyses of DNA.

It is also interesting to note that for the four species of Wikstroemia, the constant existence of caffeic acid derivatives would be worth studying in a search for chemotaxonomic markers (figure 5). We have had the opportunity to demonstrate the value of these derivatives as genus or species markers in various plants (Andary et al., 1988a, b; Andary et al., 1992).

As regards the analysis of Aquilaria spp. leaf fragments marketed as a herbal tea (called Agarwood Tea), sample No. 1 (small-scale production) had probably been subjected to tannin degradation during the preparation process, which consisted (personal communication) of initial boiling for 10-15 min, followed by drying. The leaves were then finely broken up and boiled for another $5 \mathrm{~min}$, then dried again. In addition, on the chromatogram (figure 6) for the one-dimensional thin-layer analysis of type B polyphenols (tannins), we found the appearance of unexpected molecules (reddish spots, sample No. 1) when compared to sample $N^{\circ} 2$, which corresponded to a normal tannin profile found for the species of the genus Aquilaria studied. We were unable to interpret this difference any further as we did not know the preparation process for Agarwood Tea $N^{\circ} 2$. However, it is sample No. 2 that should be used in the search for quality for commercial use.

\section{Conclusion}

This work showed the possibility of using some very old herbarium samples, since the analysis of a herbarium sample from Paris (P) herbarium, which was 140 years old, revealed good conservation of its phenolic profile when compared to a sample of the same species collected and dried just a few months earlier, despite the leaves having undergone chemical decontamination. Comparative analysis of these phenolic molecules can therefore be very useful when seeking chemotaxonomic markers.

A chemical analysis of leaves from species belonging to four genera of the Thymelaeaceae revealed a large number of polyphenols (mangiferin, coumarins, derivatives of luteolin and apigenin and caffeic acid, etc.) making up a specific phenolic profile for each of these genera. It is interesting to note that mangiferin, through its high concentration and constant presence in all the species of the genus Aquilaria analysed, constitutes a chemical marker for this genus, which is not the case for the genera Gonystylus and Wikstroemia, from which it was totally absent. However, the presence of mangiferin at very different concentrations in the three species of the genus Gyrinops studied confirmed the strong phylogenetic relation that is known to exist between Aquilaria and Gyrinops.

In addition, these results remove the uncertainty surrounding herbarium sample No. 30000 of the Poilane collection, deposited at MNHN herbarium (P) and labelled “Aquilaria baillonii or Gyrinopsis baillonii". In fact, as this sample does not contain any mangiferin, it cannot belong to the genus Aquilaria, but may belong to the genus Gyrinops.

The chromatography method we used in this analysis has the merits of being simple, practical and inexpensive. In addition, the colorimetric analysis of spots on the chromatograms belonging to various molecules gave an original result that improves the accuracy of the physicochemical authentification of chromatographed molecules contained in a plant extract.

This chromatographic analysis is not only an aid for the systematic of these species, but may also help in the in situ conservation of their genetic diversity. It may also be a traceability tool with a view to seeking species authenticity and quality in the various fields of use, as we were able to show by analysing dried leaf fragments sold in Asia as herbal tea (Agarwood Tea). This herbal tea is appreciated (cf. Aimi Zafirah et al., 2017) for its sedating, anti-inflammatory, anti-microbial and anti-diabetic qualities.

\section{Acknowledgements}

This study contributed to the framework of the project Aquilaria, Scientific and technical basis for the creation of a supply chain for top-of-the-range Aquilaria (Agarwood) essential oils and by-products in French Guiana, funded by the European Regional Development Funds (FEDER) for French Guiana (agreement n FEDER/2017/N³1).

We thank Dr. Peter Biggins (Cirad) for his excellent contribution as a translator of the manuscript.

\section{References}

Andary C., Pellecuer J., Soediro I., Privat G., 1978. Identification et dosage du verbascoside, ester hétérosidique de l'acide caféique, chez Acanthus mollis (Acanthacea). Pharmacia Mediterranea, $12: 237-249$.

Andary C., Rascol J. P., Puech S., Roussel J. L., Privat G., 1988a. Les esters de l'acide caféique dans la chimiotaxinomie des Teucrium de la section polium (Lamiaceae). Canadian Journal of Botany, 66 : 1007-1012. https://doi.org/10.1139/b88-145

Andary C., Motte-Florac M. E., Gargadennec A., Wylde R., Heintz A., 1988b. Les esters caféiques du genre Plantago. Identification et valeur chimiotaxinomique. Plantes Médicinales et Phytothérapie, 22 : 17-22. https://doi. org/10.1016/0031-9422(92)80032-A 
Andary C., Rouzet M., Lebrun L., Jourdan M., 1989. Premières recherches pharmacologiques et chimiotaxinomiques dans la canopée. In : Hallé F., Blanc P. (dir.). Biologie d'une canopée de forêt équatoriale, rapport de mission Radeau des cimes, octobre-novembre 1989. Petit-Saut, Guyane française, Association OPRDC (Opération Radeau des cimes), 162-165.

Andary C., Tahrouch S., Marion C., Wylde R., Heitz A., 1992. Caffeic glycoside esters from Jasminum nudiflorum and some related species. Phytochemistry, 31: 885-886. https://doi. org/10.1016/0031-9422(92)80032-A

Aimi Zafirah A., Shiou Yin L., Mohamed R., 2017. Pharmacological properties of agarwood tea derived from Aquilaria (Thymelaeaceae) leaves: An emerging comptemporary herbal drink. Journal of Herbal Medecine, 10: 37-44. https://doi. org/10.1016/i.hermed.2017.06.002

Bate-Smith E. C., Richens R. H., 1973. Flavonoid chemistry and taxonomy in Ulmus. Biochemical Systematics and Ecology, 1: 141-146. https://doi.org/10.1016/0305-1978(73)90004-5

Bell E. A., 1981. The physiological role of secondary products. In: Stumpf P. K., Conn E. E. (eds). Secondary Plant Products: A Comprehensive Treatise. Academic Press, 7: 11-21.

Cooper-Driver G., Swain T., 1977. Phenolic chemotaxonomy and phytogeography of Andiantum. Botanical Journal of the Linnean Society, 74: 1-21. https://doi.org/10.1111/i.1095-8339.1977. tb01162.x

Dai G. H., Andary C., Mondolot-Cosson L., Boubals D., 1995. Involvement of phenolic compounds in the resistance of grapevine callus to downey mildew (Plasmopara viticola). European Journal of Plant Pathology, 101: 541-547.

Eurling M. C. M., Gravendeel B., 2005. TrnL-trnF sequence data imply paraphyly of Aquilaria and Gyrinops (Thymelaeaceae) and provide new perspectives for agarwood identification. Plant Systematic and Evolution, 254: 1-12. https://doi.org/10.1007/ s00606-005-0312-x

Feng J., Yang X.-W., Liu T.-H., 2009. RP-LC quantification and pharmacokinetic study of iriflophenone 2-0- $\alpha$-rhamno-pyranoside in rat plasma. Chromatographia, 70: 1227-1231. https:// doi.org/10.1365/s10337-009-1279-5

Hallier H., 1922. Beiträge zur Kenntnis der Thymelaeaceen und ihner Natürlichen Umgrenzung. Mededeelingen Van's Rijksherbarium, $44: 1-31$

Hara H., Ise Y., Morimoto N., Shimazawa M., Ichihashi K., Ohyama M., linuma M., 2008. Laxative effect of Agarwood leaves and its mechanism. Bioscience, Biothechnology and Biochemistry, 72: 335-345.

Harborne J. B., Boulter D., Turner B. L. (eds), 1971. Chemotaxonomy of the Leguminosae. London, UK, Academic Press, 31-72. Hou D., 1960. Thymelaeaceae, Aquilaria. Flora Malesiana. Sijthoff \& Noordhoff International Publishers, the Netherlands, 6: 1-15.

Mabberley D. J., 2008. Mabberley’ Plant-book, 3rd edition. Cambridge University, $1021 \mathrm{p}$.

Mc Murrouch I., Mc Dowell J., 1978. Chromatographic separation and automatic analysis of flavanols. Analyst Biochemistry, 91: 92-100. https://doi.org/10.1016/0003-2697(78)90819-9

Naef R., 2011. The volatile and semi-volatile constituents of agarwood, the infected heartwood of Aquilaria species: A review. Flavour and Fragrance Journal, 26: 73-89. https://doi. org/10.1002/ffj.2034

Neu R., 1956. A new reagent for differentiating and determining flavones on paper chromatograms. Naturwissenschaften, 43: 82.
Qi S.-Y., He M.-L., Lin L.-D., Zhang C.-H., Hu L.-J., Zhang H.-Z., 2005. Production of 2-(2-phenylethyl) chromones in cell suspension cultures of Aquilaria sinensis. Plant Cell Tissue and Organ Culture, 83: 217-221. https://doi.org/10.1007/s 11240-005-5479-x

Qi J., Lu J. J., Jiu J.-H., Yu B.-Y., 2009. Flavonoid and a rare benzophenone glycoside from the leaves of Aquilaria sinensis. Chemistry and Pharmaceutical Bulletin, 57: 134-137. https://doi. org/10.1248/cpb.57.134

The Plant List, 2013. The Plant List website. Version 1.1.. Royal Botanic Gardens, Kew and Missouri Botanical Garden. http:// www.theplantlist.org/

Ueda J.-Y., Imamura L., Tezuka Y., Tran Q. L., Tsuda M., Kadota S., 2006. New sesquiterpene from Vietnamese agarwood and its induction effect on brain-derived neurotrophic factor mRNA expression in vitro. Bioorganic and Medicinal Chemistry, 14: 3571-3574. https://doi.org/10.1016/j.bmc.2006.01.023

Williams C., HarborneJ. B., MathewB., 1988. Achemical appraisal via leaf flavonoids of Dahlgren's Liliiflorea. Phytochemistry, 27: 2609-2629. https://doi.org/10.1016/0031-9422(88)87033-X

\section{Andary et al. - Contribution des auteurs}

\begin{tabular}{|c|c|}
\hline Rôle du contributeur & Noms des auteurs \\
\hline Conceptualisation & C. Andary, G. Michaloud, K. Le Cong \\
\hline Gestion des données & C. Andary, G. Michaloud \\
\hline Analyse formelle & $\begin{array}{l}\text { C. Andary, G. Michaloud, } \\
\text { D. Longepierre }\end{array}$ \\
\hline $\begin{array}{l}\text { Acquisition } \\
\text { du financement }\end{array}$ & G. Michaloud, A. Zaremski \\
\hline $\begin{array}{l}\text { Enquête } \\
\text { et investigation }\end{array}$ & C. Andary, G. Michaloud \\
\hline Méthodologie & C. Andary \\
\hline Gestion de projet & C. Andary, G. Michaloud \\
\hline Ressources & $\begin{array}{l}\text { C. Andary, G. Michaloud, S. Hul, } \\
\text { K. Le Cong }\end{array}$ \\
\hline Supervision & C. Andary, G. Michaloud \\
\hline Validation & $\begin{array}{l}\text { C. Andary, G. Michaloud, } \\
\text { D. Longepierre }\end{array}$ \\
\hline Visualisation & C. Andary, G. Michaloud \\
\hline $\begin{array}{l}\text { Écriture - Préparation } \\
\text { de l'ébauche originale }\end{array}$ & $\begin{array}{l}\text { C. Andary, G. Michaloud } \\
+ \text { traducteur externe }\end{array}$ \\
\hline $\begin{array}{l}\text { Écriture - Révision } \\
\text { et édition }\end{array}$ & C. Andary, G. Michaloud \\
\hline
\end{tabular}

Bois et Forêts des Tropiques - Revue scientifique du Cirad

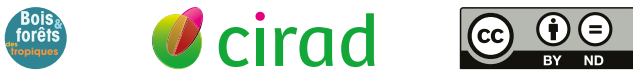

Cirad - Campus international de Baillarguet, 34398 Montpellier Cedex 5, France - Contact : bft@cirad.fr - ISSN : L-0006-579X 